\title{
KONSTRUKSI PENDIDIKAN RELASI KIAI DAN SANTRI DI PONDOK PESANTREN LINTANG SONGO PIYUNGAN YOGYAKARTA (Sebuah Pendekatan Multidisipliner)
}

\author{
Ahmad Shofiyuddin Ichsan \\ Institut Ilmu Al Qur'an (IIQ) An Nur Yogyakarta \\ Email: ahmad.shofiyuddin.ichsan@gmail.com
}

\begin{abstract}
This study aims to reveal leadership in Islamic Boarding School (Pondok Pesantren) Lintang Songo Piyungan Bantul Yogyakarta and the construction of educational relations between Kiai and santri in the context of a multidisciplinary approach. The results of the study show that there are three approaches produced. In the Normative approach, there are five things that can be revealed. 1). Straightening intentions, 2). Choosing a teacher and glorifying science and experts, 3). Learning and deliberation diligently, 4). Studying overseas and endure the difficulties which they experience, and 5). Working and praying for sufficiency. Whereas in the Psychology approach, it appears that the relationship between Kiai and santri has a very good attachment. Kiai Heri never takes the position himself as a leader and santri as subordinates, but their relationship is very intimate, like parents to their children. Furthermore, in the Sociology approach, Pondok pesantren Lintang Songo could be studied in three environments, namely material, social, and symbolic environments.
\end{abstract}

Keywords: Relationship of Kiai, Santri, Multidisipliner

\begin{abstract}
Abstrak
Penelitian ini bertujuan untuk mengungkapkan kepemimpinan di pondok pesantren Lintang Songo Piyungan Bantul Yogyakarta dan konstruksi pendidikan relasi antara kiai dan santri di pondok pesantren tersebut dalam konteks pendekatan multidisipliner. Hasil penelitian menunjukkan bahwa setidaknya terdapat tiga pendekatan yang dihasilkan. Dalam pendekatan Normatif, ada lima hal yang dapat diungkapkan. 1). Meluruskan niat, 2). Memilih guru dan mengagungkan ilmu dan ahlinya, 3). Belajar tekun dan musyawarah, 4). Belajar di perantauan dan menanggung kesusahan yang dialaminya, dan 5). Bekerja dan berdoa agar berkecukupan. Sedangkan dalam pendekatan Psikologi, terlihat hubungan kiai dan santri memiliki kelekatan yang sangat baik. Kiai Heri tidak memposisikan dirinya sebagai pemimpin dan santri sebagai bawahan, tetapi hubungan mereka sangat intim, layaknya orang tua kepada anaknya. Selanjutnya dalam pendekatan Sosiologi, pondok pesantren Lintang Songo dapat dikaji dalam tiga lingkungan, yakni lingkungan material, sosial, dan simbolik.
\end{abstract}

\section{Kata Kunci: Relasi Kiai, Santri, Multidipliner}




\section{A. Pendahuluan}

Pola pendidikan pesantren dalam sejarahnya merupakan pendidikan (yang diakui oleh banyak kalangan) telah berkontribusi besar dalam memberikan pemahaman komprehensif dalam kajian agama Islam. Lembaga pendidikan dengan pola asrama ini dalam beberapa penelitian diungkapkan terbukti sangat efektif dalam menjalankan roda proses pembelajaran. Hal ini di'iya'kan oleh Dhofir di dalam bukunya. Ia menjelaskan bahwa lembaga pendidikan dengan pola asrama seperti pesantren adalah merupakan lingkungan di mana individu tinggal dengan segala atribut yang ada tentu dapat mempengaruhi perkembangan kecerdasan emosi santri. Dan atribut pokok di pesantren yang dapat mempengaruhi santri antara lain kiai, peraturan pesantren, kurikulum dan kitab kuning (Muzakki, 2013:80).

Emosi santri di pesantren akan terkontrol karena setiap saat mereka berinteraksi satu sama lain, dan tak jarang kiai sendiri yang mengamati tingkah laku mereka. Dalam pesantren, santri hidup dalam suatu komunitas yang khas, dengan kiai, ustadz, santri dan pengurus pesantren hidup bersama dalam satu gedung (lembaga pendidikan) yang berlandaskan nilai-nilai Islam lengkap dengan norma-norma dan kebiasaan tersendiri. Pesantren merupakan suatu keluarga besar di bawah asuhan seorang kiai (ulama), dengan dibantu beberapa ustadz. Dalam dunia pesantren santri mempunyai dua orang tua, yaitu bapak-ibu yang telah melahirkannya dan kiai yang mengasuhnya selama menimba ilmu. Santri pun mempunyai dua saudara, yaitu saudara sesusunan dan saudara seperguruan sesama santri (Mastuhu, 1994:67). Maka tidak mengherankan bahwa pendidikan pesantren merupakan pendidikan keluarga kedua selain keluarga aslinya di rumah.

Pola relasi antara santri dengan kiai di pesantren sangat berbeda dengan relasi antara guru dengan siswa di sekolah. Di pondok pesantren, sosok kiai memiliki pengaruh kuat dalam perkembangan emosi santrinya. Memahami beberapa dinamika di pesantren, ada hubungan timbal balik antara keduanya. Yakni santri pada umumnya menganggap sang kiai sebagai guru sekaligus bapaknya sendiri, sebaliknya kiai juga lebih menganggap santrinya sebagai anak yang wajib diurus dan dilindungi dengan sepenuh hati. 
Dua peran kiai di sini adalah ketika kiai dijadikan sebagai guru, maka oleh santrinya ia harus memposisikan diri sebagai tempat bertanya tentang ilmu agama dan variannya. Sedangkan peran kiai sebagai orang tua adalah ketika kiai dijadikan tempat mengadu hal apapun di luar ilmu kajian agama. Di beberapa pesantren, misalnya, banyak santri senior yang sudah bertahun-tahun 'mondok' memiliki masalah ekonomi, biasanya ia mengadu ke kiainya untuk dicarikan pekerjaan. Begitu juga masalah perjodohan, santri sering berkeluh kesah ke kiai bagaimana mencari jodoh yang baik sesuai dengan kriteria santri tersebut. Maka dari itu, dijadikan tempat 'curhat' inilah yang menjadikan sosok kiai memiliki peran penting dalam membentuk karakter santrinya di kemudian hari.

Memahami hal tersebut di atas, hubungan kehidupan antara kiai dan santri sangat besar membuat kedudukan pondok pesantren memiliki banyak fungsi, baik fungsi normatif religius (tempat menimba ilmu agama), psikologis, sosial sampai pada ranah fungsi politis. Seorang kiai tidak hanya dikategorikan sebagai elite agama semata, tetapi dalam konteks pondok pesantren mereka memiliki otoritas yang tinggi, yakni sebagai penerus ulama turun temurun sampai penerus Nabi. Di titik ini sangat menarik jika relasi kiai dan santri dapat dikaji dengan pendekatan Multidipliner. Karena dengan pendekatan multidisipliner, ada kerja sama antar ilmu pengetahuan yang masing-masing tetap berdiri sendiri dengan dengan metode sendiri-sendiri (dalam memahami suatu objek penelitian). Pendekatan ini merupakan hasil interkoneksi antar satu ilmu dengan ilmu lain namun masingmasing bekerja berdasarkan disiplin dan metode masing-masing (Khoiruddin, 2016:247).

Untuk itu, dalam hal ini peneliti mencoba melihat fenomena relasi antara kiai dan santri di Pondok Pesantren Lintang Songo Piyungan Bantul. Karena di pesantren ini, ada kedekatan yang sangat kuat antara kiai beserta keluarga terhadap para santri-santrinya. Sosok KH. Heri Kuswanto sebagai pengasuh Pondok Pesantren Lintang Songo selalu menempatkan dirinya tidak selayaknya kiai pada umumnya. Justru ia mencoba menampakkan sikapnya kepada santrinya seperti layaknya teman akrab. Dengan sikap tersebut, banyak kalangan menilai sosok kiai yang satu ini sangat unik dan aneh. Ia mencoba keluar dari tatanan sosial (out of the box) yang selama ini para kiai pesantren pada umumnya lakukan. 
Dengan sikapnya yang tidak biasa tersebut, sepertinya sang kiai sudah mengkondisikan lingkungan pesantren sedemikian rupa dengan suasana kekerabatan dan kekeluargaan, maka diharapkan akan memberikan dampak kepada peningkatan emosional santri secara maksimal. Sehingga upaya-upaya pembinaan santri dengan melalui kepemimpinan kiai dilakukan secara kontinyu dengan berbagai pendekatan baik secara formal, sampai pada taraf informal personalnya.

Berdasarkan penjelasan di atas, tulisan ini akan mencoba menguraikan bagaimana kepemimpinan di dalam pondok pesantren Lintang Songo Piyungan Bantul Yogyakarta, dan bagaimana konstruksi pendidikan relasi antara kiai dan santri di pondok pesantren tersebut dalam konteks pendekatan multidisipliner. Dari kedua pembahasan tersebut setidaknya akan menjadi sumber informasi bagi para akademisi dan para agamawan dalam memahami fenomena relasi kiai dan santri di pondok pesantren, khususnya di Yogyakarta. Tulisan ini juga berguna bagi peneliti dalam memahami fenomena kehidupan pesantren dan masyarakat dalam konteks yang berbeda. Sehingga pendekatan multidisipliner mampu dimanfaatkan dalam menganalisa hal tersebut. Tidak hanya itu, tentu secara umum tulisan ini menjadi bermanfaat bagi para pembaca sebagai bagian dari sebuah informasi atau literatur tambahan dalam memahami penelitian yang sama ke depannya.

\section{B. Landasan Teori}

\section{Kepemimpinan Kiai Pesantren}

Seorang pemimpin dalam mendayagunakan kepemimpinannya dalam suatu komunitas mempunyai fungsi yang harus diemban oleh seorang pemimpin yaitu mengoptimalisasikan kelebihan yang dimiliki oleh seorang pemimpin tersebut dalam mencapai suatu tujuan. Demikian pula di kalangan pondok pesantren seorang kiai sebagai pendiri dan pemimpin sebuah pesantren yang menyebarkan dan mendalami ajaran-ajaran dan pandangan Islam, maka dengan sendirinya peran kiai di pesantren tidak hanya sebagai pemimpin di pondok pesantren yang tentu harus dijalankan secara total dan ikhlas dalam mengajar dan memberi bimbingan keagamaan kepada santrinya. Kiai juga harus bijaksana dalam memberikan solusi permasalahan di masyarakat sekaligus selalu menyesuaikan kondisi kehidupan 
masyarakat di sekitarnya tersebut. Hal ini menjadi 'rahasia umum' dalam realitas masyarakat, apalagi masyarakat di daerah pedesaan (Mahasin, 2017).

Kepemimpinan kiai di pondok pesantren adalah kepemimpinan pribadi (personal) segala masalah kepesantrenan bertumpu pada sosok kiai, yang akhirnya timbul corak kepemimpinan yang sangat bersifat individualistik yang berlandaskan pada penerimaan masyarakat sekitar secara mutlak. Fenomena ini karena ciri utama kepemimpinan kiai adalah watak kharismatik. Tetapi berjalannya waktu, ada perubahan dalam kepemimpinan kiai tersebut. Mastuhu mengatakan bahwa, ada kecenderungan terjadinya perubahan secara gradual antara gaya kepemimpinan pesantren yang satu dengan yang lain. Kecenderungan perubahan tersebut : 1) Dari jenis kharismatik menuju ke rasional; 2) Dari otoriter kebapakan menuju ke diplomatik partisipatif; 3) Dari laiser-faire menuju ke birokratis (Mastuhu, 1994:89).

Menurut pandangan peneliti, perubahan jenis kepemimpinan kharismatik kiai ke arah rasional merupakan sebuah kewajaran. Tetapi rasional di sini tidak bisa merubah total tentang 'gelar patron' kharismatiknya sejak dulu. Dalam konteks kiai di pondok pesantren Lintang Songo Piyungan, misalnya, sosok kiai sangat rasional dalam bertindak dan berkomunikasi dengan santrinya, tetapi 'aura' kharismatik kiai itu sendiri masih sangat terlihat jelas. Fenomena kepemimpinan kiai saat ini bisa dikatakan sebagai "mix leadership" dalam artian kepemimpinannya memiliki sinergi satu sama lainnya. Seorang kiai yang kharismatik, juga rasional, dan partisipatif. Tentu pola kepemimpinan seperti ini tidak bisa disamaratakan dengan kepemimpinan-kepemimpinan pesantren di seluruh Indonesia. Karena satu pesantren dengan pesantren lainnya masih memiliki perbedaan yang cukup signifikan dalam hal gaya kepemimpinan.

Menjadi penting juga untuk dijelaskan di sini bagaimana tipologi kepemimpinan pondok pesantren selama ini. Sulthon Masyhud menerangkan bahwa setidaknya ada tiga tipologi kepemimpinan yang telah harus dipahami di dalam ruang lingkung pendidikan di pondok pesantren (Masyhud, 2005:29), di antaranya adalah: 1) Kepemimpinan Kultural Pesantren. Dalam kepemimpinan ini, peran kiai menjadi taruhan dalam menjaga fluktuasi progresivitas pesantren itu sendiri. Secara kultural, peran kiai harus menjadi titik sentral dalam mencetak 
generasi baru yang secara hierarkis dilakukan, yakni mencetak santri yang alim, bermoral, kharismatik, revolusioner, dan seterusnya. Maka dari itu, sistem hierarki yang mengandung silsilah, sanad, dan jaringan yang bersifat berkesinambungan dalam diri kiai inilah menjadi penentuan kualitas keilmuan dan keulamaannya, sehingga hal ini menjadi penting dalam tradisi (kultur) pesantren yang terus dilestarikan sampai saat ini.

2) Kepemimpinan Strategik Pesantren. Dalam kepemimpinan ini, setidaknya harus dilihat dari tiga hal, di antaranya: a). Waktu, b). Skala isu, dan c). Lingkup tindakannya. Seorang kiai yang memiliki tipologi ini, ia harus menunjukkan dalam memilih dan memilah isu-isu strategis dalam dunia pesantren. Maka tidak jarang, banyak sosok kiai sebagai pimpinan pusat pondok pesantren aktif menyimak perkembangan zaman, mulai dari tingkat lokal setempat, global, maupun tingkat internasional. Sehingga dengan adanya sikap tersebut, kiai mampu memiliki kearifan dalam mengidentifikasi sesuatu secara analisis SWOT, yakni Stregths (kekuatan), Weaknesess (kelemahan), Opportunities (kesempatan), dan Threats (ancaman), yang mungkin muncul dalam kehidupan di pesantren dan di masyarakat.

3) Kepemimpinan Pendidikan Pesantren. Untuk melihat kepemimpinan ini, kita harus melihat sifat dan sikap sosok pemimpin dalam dunia pendidikan. Meneropong dari sisi ini, sosok kiai harus memiliki tanggung jawab, perhatian dalam segala hal (khususnya pada setiap santri), berani mengambil resiko, percaya diri dan terampil dalam mengendalikan situasi, dan mampu mempengaruhi serta memberi motivasi dalam rangka mencapai tujuan dan harapan yang ditetapkan.

Tidak bisa dipungkiri bahwa pesantren merupakan pendidikan tertua dalam sejarah pendidikan Indonesia. Ia telah memberikan kontribusi penting dalam peradaban kehidupan masyarakat, khususnya dalam membingkai kehidupan keberagamaan dan Kebangsaan. Oleh karenanya, kepemimpinan pendidikan pesantren mempunyai ciri khas tertentu yang sudah lama mengakar, sehingga dalam kepemimpinan tersebut memiliki dampak yang luas dan berkontribusi nyata dalam realitas kekinian. 


\section{Pendekatan Multidisipliner}

Pendekatan multidisipliner ialah pendekatan dalam pemecahan suatu masalah dengan menggunakan tinjauan berbagai sudut pandang banyak ilmu yang relevan. Ilmu ilmu yang relevan digunakan bisa dalam rumpun Ilmu Ilmu Kealaman (IIK), rumpun Ilmu Ilmu Sosial (IIS), atau rumpun Ilmu Ilmu Humaniora (IIH) secara alternatif. Penggunaan ilmu-ilmu dalam pemecahan suatu masalah melalui pendekatan ini dengan tegas tersurat dikemukakan dalam suatu pembahasan atau uraian termasuk dalam setiap urai sub-sub uraiannya bila pembahasan atau uraian itu terdiri atas sub-sub uraian, disertai kontribusinya masing masing secara tegas bagi pencarian jalan keluar dari masalah yang dihadapi. Ciri pokok atau kata kunci dari pendekatan multidisipliner ini adalah multi, yakni banyak ilmu dalam rumpun ilmu yang sama (Sudikan, TT:45).Menurut Khoiruddin Nasution, dalam bukunya Pengantar Studi Islam, menjelaskan bahwa pendekatan Multidisipliner merupakan kerja sama antar ilmu pengetahuan yang masing-masing tetap berdiri sendiri dengan dengan metode sendiri-sendiri. Disebut juga multidisipliner adalah interkoneksi antar satu ilmu dengan ilmu lain namun masing-masing bekerja berdasarkan disiplin dan metode masing-masing. Masih dalam definisi lainnya, Multidisiplin adalah pendekatan dalam pemecahan suatu masalah dengan menggunakan berbagai sudut pandang banyak ilmu yang relevan (Khoiruddin, 2016:247).

\section{Metode Penelitian}

Penelitian ini adalah penelitian yang bersifat kualitatif (qualitative research) yang memiliki tujuan untuk mendeskripsikan dan menganalisa fenomena, peristiwa, aktivitas sosial, sikap, persepsi, serta pemikiran orang lain, baik secara individual maupun sosial (Sukmadinata, 2008:60), yang dalam hal ini memfokuskan pada konstruksi relasi kiai dan santri di pondok pesantren Lintang Songo Piyungan Bantul. Sedangkan penelitian yang digunakan adalah penelitian kualitatif naturalistik. Hal ini dikarenakan konteks objek yang dikaji memerlukan kajian tersendiri dalam hal deskriptif komprehensif dengan tujuan memahami makna peristiwa dan kaitannya pada lingkungan pondok pesantren Lintang Songo dan orang-orang di dalamnya. Sedangkan naturalistik sendiri adalah penelitian yang dilakukan secara alami sesuai dengan realitas keadaan yang ada, tanpa 
adanya manipulasi dalam setting penelitiannya (Moleong, 2001:3). Adapun jenis penelitian yang dipakai adalah dengan menggunakan studi kasus (case study) (Hadari, 2003:1).

Penelitian ini memusatkan diri secara intensif pada sosok kiai dan santri di pondok pesantren Lintang Songo dengan mempelajarinya sebagai suatu kasus. Data studi kasus dapat diperoleh dari semua pihak yang memiliki relevansi kuat terhadap objek yang diteliti di pesantren tersebut. Dengan kata lain, dalam studi ini dikumpulkan berbagai sumber dalam konteks kevalidan informasi yang ada. Adapun objek yang diteliti di sini adalah pengasuh Pondok Pesantren Lintang Songo Piyungan Bantul Yogyakarta (KH. Heri Kuswanto), keluarga ndalem (kiai), para ustad beserta santri-santrinya.

Data diperoleh dari penelitian ini melalui wawancara langsung dengan kiai, beberapa ustad dan santri, baik santri mukim maupun santri 'kalong' (non mukim). Data juga diperoleh melalui observasi dengan menginap langsung di pesantren untuk memahami bagaimana realitas lingkungan pesantren sekaligus lingkungan masyarakat sekitarnya. Tidak hanya itu, data juga diambil melalui berbagai dokumentasi yang berhubungan dengan penelitian sebagai bagian dari validitas dan reliabilitas data.

Teknik analisis data yang digunakan dalam penelitian ini adalah dengan menggunakan analisa model Miles dan Huberman. Adapun aktivitas dalam analisa model ini yaitu: 1). Reduksi data (data reduction). Teknik ini berusaha menyederhanakan temuan data dengan cara mengambil intisari data sampai ditemukan tema pokok, sehingga dengan itu dapat memberikan gambaran yang jelas, 2). Penyajian data (data display). Teknik ini dapat dilakukan dengan bentuk uraian singkat, bagan, hubungan antar kategori sehingga keseluruhan dan bagian detail-detailnya dapat dipetakan dengan jelas, dan 3). Penarikan kesimpulan (conclusion drawing/verification). Teknik ini dilakukan setelah data yang disajikan sudah memenuhi syarat sehingga hasilnya dapat ditarik sebuah kesimpulan (Sugiyono, 2015:337-345).

\section{Hasil}

Cikal bakal berdirinya pesantren ini dimulai sejak tahun 1991 oleh kiai Heri, panggilan akrab dari $\mathrm{KH}$. Heri Kuswanto. Beliau merupakan putra dari $\mathrm{KH}$ 
Muhammad Zaidan, seorang ulama sepuh yang telah mengabdikan hidupnya untuk berdakwah di berbagai daerah Yogyakarta dan sekitarnya. Pada bulan Mei 2006, oleh H. San Afri Awang (dosen dan salah satu pimpinan di Fakultas Kehutanan Universitas Gadjah Mada Yogyakarta) bersama kiai Heri bersepakat dalam memberikan nama pesantrennya tersebut dengan nama ISC (Islamic Studies Centre). Kemudian oleh masyarakat disebut sebagai pondok pesantren yang diberi nama Aswaja Lintang Songo, sehingga nama lengkapnya adalah Pondok Pesantren ISC Aswaja Lintang Songo.

Pesantren dengan nama ini, diharapkan menjadi lembaga pendidikan Islam yang menjadi pusat kajian ilmu-ilmu agama Islam yang memiliki 'ideologi' Ahlussunnah wal Jamaah dan berkarakter "Lintang Songo". Songo (sembilan) merupakan angka terbesar dan lintang (bintang) sembilan merupakan bagian dari simbol Walisongo sekaligus simbol nahdlah atau kebangkitan (Islam melalui para ulamanya).

Pada tahun 2006, kiai Heri bersama KH. Haris Gufron (Pondok Pesantren Al Imam Wonokromo, Bantul), KH. Fairuzi Afiq (Pondok Pesantren Nurussalam Krapyak, Yogyakarta) dari RMI, dan KH. Habib Masyhur Ridlo Al Hasany mengupayakan berdirinya gedung untuk pesantren ini. Survei AIP/AustraliaIndonesian Partnership (sebuah kemitraan Indonesia dan Australia dalam bidang pembangunan ekonomi masyarakat) yang dilalukan oleh Mr. Andrew, Mr. Allan, dan Mr. Bill pun akhirnya menghasilkan bantuan gedung yang pada saat itu senilai 580 juta. Bantuan tersebut berupa lima lokal gedung, yakni 2 ruang kelas, 1 kantor, 1 perpustakaan dan 1 dapur berikut perabotnya, serta empat unit toilet. Bantuan gedung tersebut akhirnya diresmikan pada 3 November 2007 oleh Kedutaan Australia dan Bupati Bantul (NU Online. 2013).

Secara demografi, pondok pesantren Lintang Songo berlokasi di desa Pagergunung 1 Sitimulyo Piyungan Bantul Daerah Istimewa Yogyakarta. Pesantren ini berlokasi di $15 \mathrm{~km}$ ke timur laut pusat kota Yogyakarta. Dari sebelah utara, pesantren ini berdekatan dengan wilayah Kabupaten Sleman, yakni kecamatan Berbah. Dari sebelah timur, pesantren ini berdekatan dengan kabupaten lainnya, yakni kecamatan Patuk Kabupaten Gunungkidul. Dari sebelah 
selatan, pesantren ini bersebelahan dengan kecamatan Pleret Bantul. Sedangkan dari sebelah Barat, pesantren ini berdekatan dengan wilayah Kota Yogyakarta.

Hingga penelitian ini dilakukan, pesantren Lintang Songo ini terus mengalami perkembangan. Perbaikan dalam hal kuantitas dan kualitas santri, pembangunan gedung dan kamar-kamar santri, pengaktualisasikan program individual santri, sampai pada program sosial kemasyarakatan. Dalam visi dan misi pesantren Lintang Songo, kiai Heri mengatakan bahwa visi dan misi pesantren adalah agar santri bisa menjadi insan berkualitas, mandiri, dan bermanfaat bagi masyarakat (observasi peneliti, 12 Februari 2019).

Dalam konteks relasi antara kiai dan santri, kiai Heri sangat akrab dengan santri-santrinya. Bahkan di beberapa hal, kiai Heri melakukan hal yang sama dengan para santrinya. Yakni setiap pagi pergi bersama di kebun untuk bercocok tanam dan menyirami tanaman di wilayah pesantren. Kiai Heri juga bersama santri memiliki kebiasaan yang unik, misalnya makan bersama santri. Bahkan lauk yang dihidangkan untuk keluarga kiai, sama persis dengan apa yang dimakan oleh santri-santrinya. Dalam komunikasi, kiai Heri dengan santrinya selalu menjalin komunikasi dengan bahasa 'pasaran', yakni bahasa anak muda dan masyarakat pada umumnya.

Memahami beberapa hal yang tidak lazim dilakukan oleh sang kiai ini, tampaknya kiai Heri sangat menyadari bahwa apa yang dilakukannya merupakan sikap yang harus terus dijalankan. Karena menurutnya, santri di pesantren Lintang Songo merupakan santri yang memiliki berbagai macam karakter dan latar belakang yang berbeda. Perbedaan tersebut sangat terasa karena para santri di pesantren ini tidak hanya santri biasa, tetapi juga mantan preman, bandar judi, keluarga broken home, fakir miskin, dhu'afa'. sudah usia lanjut, sampai pada santri yang gila. Jadi pendekatan yang unik tersebut merupakan alat untuk interaksi yang kuat demi menjaga kekeluargaan antara kiai dan santri. Pendekatan ini sekaligus menjadi bagian pendidikan tersendiri bahwa menjalin relasi dengan orang yang memiliki banyak perbedaan harus dilakukan secara bijaksana dan dikaji secara mendalam dengan tetap memanusiakan satu sama lain (hasil observasi dan wawancara personal, 12 Februari 2019). 
E. Pembahasan

\section{Konstruksi Pendidikan Relasi Kiai dan Santri: Sebuah Pendekatan Multidisipliner}

Memahami relasi kiai dan santri di pondok pesantren Lintang Songo Piyungan Bantul, bagi peneliti menggunakan pendekatan Multidisipliner sangat tepat untuk melihat fenomena tersebut. Karena dengan pendekatan Multidisipliner akan mampu memecahkan suatu masalah atau mengungkapkan objek kajian tertentu dengan menggunakan tinjauan berbagai sudut pandang ilmu yang relevan.

Kajian tentang relasi kiai dan santri di pesantren pada dasarnya sudah banyak yang mengkajinya, tetapi kebanyakan tertuju pada pembahasan ilmu akhlaq Islam semata, ada pula mengkaitkannya dengan psikologi dalam hal emosional santri. Tetapi dalam kaitan kajian beberapa pendekatan sampai saat ini belum pernah ada, apalagi objek kajiannya pada sosok kiai yang unik. Sehingga penelitian ini sangat menarik untuk dianalisis, karena setiap disiplin ilmu tentu mempunyai pendekatan yang berbeda-beda dengan objek yang sama.

Maka dari itu, dalam memahami fenomena kiai unik dalam relasinya terhadap santri di pondok pesantren Lintang Songo Piyungan Bantul, di sini peneliti mencoba menganalisa dengan pendekatan Multidisipliner, yakni sebagaimana berikut:

\section{Sebuah Analisa dalam Pendekatan Normatif (Agama)}

Pendekatan normatif adalah studi Islam yang memandang masalah dari sudut legal formal dan atau normatifnya. Maksud legal formal adalah hubungannya dengan halal-haram, boleh atau tidak, dan sejenisnya. Sementara normatifnya adalah seluruh ajaran yang terkandung dalam nash. Dengan demikian pendekatan normatif mempunyai cakupan yang sangat luas. Sebab seluruh pendekatan yang digunakan oleh ahli usul fiqih (usuliyah), ahli hukum Islam (fuqaha), ahli tafsir (mufassirin) yang berusaha menggali aspek legal formal dan ajaran Islam dari sumbernya adalah termasuk pendekatan normatif (Khoiruddin, 2016:190).

Untuk menganalisa relasi kiai dan santri dalam pendekatan Normatif ini, peneliti menggunakan perspektif kitab Ta'limul Muta'alim karya Syaikh Burhanuddin Az Zanurji. Dalam kitab tersebut dijelaskan bagaimana relasi 
antara seorang murid dengan gurunya. Setidaknya ada lima hal yang perlu dijelaskan. Pertama, meluruskan niat. Kedua, memilih guru dan mengagungkan ilmu dan ahlinya. Ketiga, belajar tekun dan musyawarah. Keempat, belajar di perantauan dan menanggung kesusahan yang dialaminya. Kelima, bekerja dan berdoa agar berkecukupan (Al Zanurji, TT).

a. Meluruskan Niat

Di pondok pesantren Lintang Songo, terdapat tiga kitab akhlaq yang diajarkan oleh para ustadznya, yakni kitab Ta'limul Muta'allim, Akhlaqul Banin dan Taisirul Khollaq. Menurut penuturan salah satu ustad di pesantren tersebut, setiap beberapa kali pertemuan pengajian kitabnya, dia mengingatkan kepada semua santri di kelasnya untuk meluruskan niat kembali. Niat dalam menuntut ilmu antara lain mencari ridha Allah, menghilangkan kebodohan atau ketidaktahuan dari diri sendiri dan orang lain dan pada akhirnya untuk menghidupkan agama.

"Tidak hanya ngaji harian, setiap Selasa malam juga terdapat pengajian rutin, yang di sini disebut "Ngaji Reboan", kiai Heri sering mengingatkan kepada santri dan masyarakat untuk melakukan tajdidun niat (memperbaiki niat kembali). Karena dengan itu, amalan kita semua tidak sia-sia dan diganjar oleh Allah SWT dengan ganjaran (pahala) yang berlipat ganda" (Anwar, 2019).

b. Memilih Guru dan Mengagungkan Ilmu dan Ahlinya

Doktrin terkuat dalam tradisi pesantren yang berlandaskan kitab Ta'lim adalah hormat atau takzim guru. Hal ini sudah menjadi lazim dan disadari oleh umat Islam. Begitu juga oleh santri-santri di pondok pesantren Lintang Songo. Walaupun kiai memiliki sifat egaliter dalam berinteraksi dan bersikap kepada para santrinya, tetapi penghormatan santri terhadap seorang kiai masih terlihat ditekankan. Karena sekali lagi, kiai Heri bagi mereka bukan hanya beliau adalah sosok guru yang harus dimuliakan karena kealiman ilmunya, tetapi juga sosok ayah kedua (pengganti orang tuanya di rumah). Sehingga sangat wajar para santri juga menghormatinya sekaligus keluarga dan para kerabatnya. Dalam pendidikan, tentu memuliakan guru adalah sesuatu yang harus dilakukan. Di samping akan menimbulkan perhatian dan kecintaan guru terhadap muridnya, di saat yang 
sama juga akan meningkatkan martabat dari murid itu sendiri (Nata, 2016:11).

Terkait memilih guru dalam kitab Ta'limul Muta'alim, salah satu santri di pondok pesantren Lintang Songo menuturkan bahwa ia sangat beruntung bisa bertemu kiai Heri dan bisa mondok di pesantren ini. Karena dengan hidup di pesantren ini, ia bisa setiap saat ketemu dan berinteraksi dengan kiai. Mungkin beda dengan pesantren lainnya, terkadang antara santri dan kiai jarang ditemui karena banyaknya santri dan luasnya wilayah pesantren. Oleh karenanya, ia bisa mencari guru yang alim (agama dan sosial), dan bisa memberikan solusi setiap apapun yang ia keluhkan. Dan itu baginya, ada di sosok kiai Heri (Syifa. 2019). Hal ini menjadi bukti bahwa memilih guru merupakan bagian fundamental dalam menapai ketenangan dalam hidup seseorang. Dengan mengagungkan kealiman dan keilmuannya, bagaimana sosok guru telah dijadikan 'referensi shahih', sehingga dengan itu akan menentukan bagaimana corak kehidupan santri ke depannya.

c. Belajar Tekun dan Musyawarah

Di pondok pesantren Lintang Songo, banyak kisah santri yang ketika di pesantren 'terbelakang' dalam keilmuan dan etika/sopan santun yang kurang, namun ia tetap ikhlas menjalani rutinitas mengaji, senantiasa tekun dalam belajar, terus mengabdikan diri apapun yang dititahkan kiai. Ketika ia telah pulang dan terjun di tengah masyarakat, justru menjadi 'orang' (sukses) dan 'diorangkan' (dihargai masyarakat), sehingga dalam hidupnya terus memberi manfaat kepada orang-orang di sekitarnya. Hal ini terbukti, sejak 2001 pesantren ini didirikan, sudah puluhan bahkan ratusan santri yang menjadi alumninya. Banyak di antara para alumni menjadi orang sukses, seperti dosen, pegawai negeri, da'i, guru di sekolah, dan seterusnya. Maka tidak mengherankan setiap pengajian rutin bulanan "Selasa Kliwon", banyak alumni yang masih berdomisili di wilayah Yogyakarta masih menyempatkan hadir dalam pengajian tersebut.

Walaupun pengajian ilmu agama di pondok pesantren Lintang Songo masih dalam tingkatan kitab-kitab Islam yang dasar, tetapi dengan ilmu dasar itu mampu memberikan manfaat nyata bagi banyak orang. Jika dilihat 
dari keseharian santri mengaji, ilmu dasar yang diajarkan oleh kiai dan para ustad selalu disertai dengan ajakan diskusi/musyawarah. Dalam artian, teori yang telah dikaji di kitab, harus dipahami dalam realitas yang terjadi di masyarakat. Maka dari itu, istilah al-futuh (terbukanya pemahaman melalui hati) yang dilakukan para santri disebabkan adanya ketekunan, keikhlasan, riyadah (melatih membiasakan diri beribadah secara serius) dan terus bermusyawarah dalam mengkaji ilmu agama. Sehingga nilai-nilai religius dan etika dari diri santri tampak karena mendapatkan ilmu yang berkah dan manfaat (Hidayah, 2018:161).

d. Belajar di Perantauan dan Menanggung Kesusahan yang Dialaminya

Mencari ilmu di perantauan dan jauh dari tempat asal juga sangat baik bagi para pencari ilmu, di samping untuk mendapatkan pengalaman, tetapi juga untuk melatih kemandirian dan kedewasaan dalam hal apapun. Para santri di pondok pesantren Lintang Songo juga demikian, banyak santri dari berbagai daerah di Indonesia menimba ilmu di pesantren ini. Menurut penuturan kiai Heri, ada pula beberapa kali santri asal pulau luar Jawa yang umurnya sudah 70 tahun lebih ikut bermukim dan mengaji di pesantren ini (Heri. 2019). Hal ini tentu menarik bagaimana memahami individu yang jauh dari orang tua untuk belajar mencari ilmu di perantauan dan menanggung semua resiko di dalamnya.

Pada umumnya, santri harus menanggung kesusahan selama menimba ilmu di pesantren. Tetapi kesusahan yang dialami oleh para santri selama ini diupayakan oleh kiai untuk dicarikan solusi bersama. Sehingga santri di sini tidak merasa sendiri, karena apa yang ia rasakan akan dirasakan pula oleh teman dan kiainya. Maka menjadi benar apa yang disampaikan oleh Imam Syafi'i dalam syairnya mengatakan, "Siapa tidak mencicipi pahitnya belajar walau sesaat, ia akan menelan hinanya kebodohan sepanjang hidupnya. Barangsiapa waktu mudanya tidak sempat belajar, bacakan takbir empat kali untuk kematiannya" (http://www.nu.or.id/). Sehingga dengan syair ini, akan menjadi cambuk bagi santri-santri di pondok pesantren Lintang Songo bahwa tidak ada yang susah di dunia ini jika berniat untuk ibadah kepada Allah melalui pencarian ilmu agama di pesantren. 
e. Bekerja dan Berdoa Agar Berkecukupan

Karena semua manusia memiliki harapan hidup yang layak, juga begitupun santri. Setelah usai menimba ilmu di pesantren, pastilah ia akan bergelut dengan urusan dunia, baik mendapatkan pekerjaan yang layak, sampai pada kesuksesan menjadi orang kaya. Hal ini sejak awal sudah diantisipasi oleh kiai Heri kepada santri-santrinya. Sehingga ketika awal santri masuk di pesantren, mereka tidak hanya diajarkan mengaji agama semata, tetapi secara langsung juga diajarkan tata cara 'mengaji' perihal pertanian, perikanan, dan bisnis jual beli.

Berdasarkan hasil observasi, para santri di pondok pesantren Lintang Songo memiliki banyak skill karena selama di pesantren mereka diajarkan banyak ilmu pengetahuan. Saat ini para santri baru tidak hanya sudah bisa menjadi imam tahlilan dan yasinan, tetapi mereka sudah bisa membuat roti dan sabun cair untuk dijual di toko-toko terdekat. Santri juga diajarkan budi daya ikan, sehingga hasilnya digunakan oleh para santri sendiri. Selain itu, terdapat pula beberapa santri yang tidak memiliki aktivitas selain ngaji di pesantren (baca: tidak sekolah/kuliah), kiai Heri mencarikan mereka pekerjaan secara layak dan mendapat gaji bulanan. Dari berbagai pemberian ilmu pengetahuan sekaligus 'praktikumnya' ini, akan menjadi sesuatu yang lumrah karena hal ini sudah dilakukan oleh kiai sejak pesantren ini didirikannya (Observasi, 22-23 Januari 2019).

Maka dari itu, konstruksi pendidikan relasi kiai dan santri di pondok pesantren Lintang Songo, bagi peneliti, sangatlah unik. Maka tidak mengherankan banyak santri di pesantren ini tidak hanya pandai dalam ilmu agama, tetapi juga mereka memiliki kecakapan dalam pertanian, perikanan, bisnis, dan sosial sebagaimana mereka lalui dengan kiai Heri dalam aktivitas kesehariannya.

\section{Sebuah Analisa dalam Pendekatan Psikologi}

Untuk memahami relasi kiai dan santri di pondok pesantren Lintang Songo dalam pendekatan Psikologi, peneliti mencoba menggunakan teori Hubungan Interpersonal dari John Bowlby. Menurutnya, teori Hubungan Interpersonal adalah sebuah landasan berpikir mengenai hubungan gaya kelekatan pada masa 
dewasa. Teori ini juga menjelaskan bahwa kelekatan adalah hubungan timbal balik antara dua orang yang mempengaruhi kualitas hubungan keduanya tersebut. Kelekatan juga mengacu pada suatu hubungan antara dua orang yang memiliki perasaan yang kuat satu sama lain dan melakukan banyak hal bersama demi melanjutkan hubungan tersebut (Cenceng, 2015:143). Kelekatan tidak selamanya ditujukan kepada figur lekat utama atau orang tua. Kelekatan juga bisa ditujukan kepada orang-orang tertentu. Orang-orang tertentu ini, yaitu figur lekat (significant other). Ada dua macam figur lekat pengganti, yakni figur lekat utama dan figur lekat pengganti (Fithrotien, 2015:3).

Di pondok pesantren Lintang Songo, sebagaimana hasil observasi peneliti, hubungan kiai dan santri memiliki kelekatan yang sangat baik. Kiai Heri tidak memposisikan dirinya sebagai pemimpin dan santri sebagai bawahan, tetapi di sini hubungan mereka seperti orang tua dan anak (yang masing-masing mengharapkan ridha Allah pada setiap kehidupannya). Walaupun di beberapa tempat, relasi kiai dan santri begitu jauh. Kiai sebagai pemimpin, yang semestinya menempatkan santri sebagai 'bawahan'. Di sini kiai Heri menunjukkan 'keunikannya', yakni mampu keluar dari kebiasaan yang melekat pada umumnya pesantren yang ada. Hal ini terbukti ketika peneliti observasi di pesantren, kiai Heri mengajak peneliti makan bersama-sama dengan ibu Nyai dan para santri-santrinya di teras asrama putri.

Jadi ada anggapan bahwa relasi kiai dan santri dapat menutup ruang dialog dan diskusi antara keduanya, justru di pondok pesantren Lintang Songo, kiai dan santri bisa berdialog dan berbincang kapanpun dan dalam konteks apapun. Maka menjadi wajar jika sebagian besar santri di pondok pesantren Lintang Songo ini menganggap kiai Heri adalah sosok figur lekat pengganti dari ayah kandung yang berada di rumah. Dijadikan sebagai representasi orangtua inilah menjadikan santri-santri merasa ada kenyamanan, keamanan, dan kebahagiaan dalam mengarungi waktu demi waktu di pesantren. Kelekatan antara kiai dan santri ini menjadi perasaan yang kuat satu sama lain, sehingga harapan dan tantangan yang dihadapi santri dapat terlalui dengan baik.

Di sisi lain, peneliti melihat ada beberapa santri yang masih merasa segan berdekatan dengan kiai. Hal ini dapat dikaji dari beberapa alasan. Pertama, ia 
malu karena belum bisa berbahasa dengan baik, sehingga ada 'ewuh pekewuh' (merasa tidak nyaman) jika berkomunikasi dengan kiai. Ia takut ada kesalahan ucap dan sikap. Kedua, ia merasa masih sangat takut komunikasi dengan kiai secara 'fulgar' karena ia belum lama di pesantren. Ia lebih pada bersikap diam untuk beradaptasi dengan lingkungan sekitar. Ketiga, ia merasa tidak nyaman dengan kiai karena ia merasa masih banyak dosa dan salah dalam dirinya. Ia mengakui sebelum masuk pesantren, ia merupakan mantan preman jalanan yang memiliki kehidupan yang jauh dari dunia pesantren. Oleh karena itu, ia harus bersikap menjaga diri dengan kiai, karena baginya kiai adalah 'orang suci’ yang berbeda dengan dirinya (Heru. 2019).

Terlepas dari beberapa santri yang masih merasa segan dengan kiai di atas, pada dasarnya semua santri merasakan kenyamanan tinggal di pesantren. Walaupun mereka merasa segan, kelekatan relasi antara kiai Heri dengan santrinya tersebut masih terjalin dengan harmonis. Kebutuhan akan kelekatan untuk aman, nyaman dan bahagia merupakan suatu keniscayaan bagi perkembangan psikologis santri. Karena kelekatan tersebut merupakan tahapan penting dalam proses relasi santri dengan kiai, dengan harapan ke depan mereka mampu memberikan kelekatan yang sama secara baik di masyarakat sekitar.

\section{Sebuah Analisa dalam Pendekatan Sosiologi}

Dalam telaah pendekatan sosiologi, peneliti dalam hal ini menggunakan teori Sosiologi Humaniora dari Kuntowijoyo. Dalam teori ini, Kuntowijoyo menjelaskan adanya tiga lingkungan tempat manusia hidup, yaitu lingkungan material, lingkungan sosial, dan lingkungan simbolik. Setidaknya ini akan membantu dalam memperjelas maksud yang dikehendaki dari penelitian ini. Lingkungan material adalah lingkungan buatan manusia, seperti rumah, jembatan, sawah, dan peralatan-peralatan. Lingkungan sosial ialah organisasi sosial, stratifikasi, sosialisasi, gaya hidup dan sebagainya. Adapun lingkungan simbolik adalah sesuatu yang meliputi makna dan komunikasi, seperti kata, bahasa, mitos, nyayian, seni, upacara, tingkah laku, benda-benda, konsepkonsep, dan sebagainya (Kuntowijoyo, 2006: 89). 
Ernst Cassier, sebagaimana dikutip Kuntowijoyo, menambahkan bentukbentuk simbolik itu juga meliputi agama, filsafat, ilmu, dan sejarah. Dalam konteks ini, humaniora dipahami sebagai sebuah kerangka pendidikan pembebasan (liberal education) yang mengajarkan perihal wisdom, yakni mendidik bagaimana menjadi manusia. Ta'rif terhadap humaniora seperti ini sejalan dengan maksud yang dikehendaki dari lingkungan simbolik tersebut, sebab mendidik bagaimana menjadikan manusia manusiawi, dalam arti berbudaya, adalah suatu sikap atau tindakan yang sarat dengan makna (Kuntowijoyo, 2006:90). Manusia sudah tidak lagi semata-mata hidup di alam semesta fisik, tetapi justru saat ini manusia hidup dalam semesta simbolik (Driyanti, 2011:4).

Memahami tiga lingkungan tempat manusia hidup dari Kuntowijoyo di atas, di pondok pesantren Lintang Songo juga dapat dikaji dari ketiga lingkungan tersebut.

\section{a. Lingkungan Material}

Lingkungan material yang diungkapkan oleh Kuntowijoyo adalah rumah, kamar, jembatan, sawah, dan peralatan-peralatan lainnya. Jika kita kaitkan dengan situasi lingkungan material di pondok pesantren Lintang Songo, lingkungan material di pesantren tersebut memiliki hubungan positif dan signifikan terhadap konstruksi pendidikan relasi kiai dan santri di sana.

Secara geografis, lingkungan material di pesantren ini sedikit berbeda dengan lingkungan pesantren lainnya. Dari sisi gedungnya, gedung asrama santri putra dibedakan jauh dari gedung asrama santri putri. Kediaman kiai Heri sendiri tidak ada sekat dan batas wilayah kediamannya dengan wilayah asrama santri. Dalam artian, antara kediaman kiai dan asrama santri menyatu menjadi satu gedung. Pola setting seperti ini menjadikan lingkungan material di pesantren ini dapat terlihat jelas, sehingga setiap saat antara kiai dan santri saling berinteraksi tanpa adanya sekat yang berlebihan.

Tidak hanya itu, lingkungan material lainnya yang menjadi 'alat' relasi sosial kiai dan santri adalah perkebunan dan persawahan milik 
pesantren. Pada tahun 2017, pondok pesantren Lintang Songo diberikan penghargaan dari Kementerian Pertanian sebagai juara satu Pesantren Berwawasan Lingkungan Hidup tingkat provinsi. Hal ini dapat disadari bahwa sejak didirikan, kiai terus mengembangkan banyak hal tentang perbaikan di berbagai lingkungan pesantren. Perkebunan pesantren, misalnya, telah digunakan sebagai wahana perkebunan buah-buahan seperti pepaya, jeruk nipis, tomat, cabai, kubis, bawah merah dan seterusnya. Persawahan digunakan untuk bercocok tanaman padi, jagung dan palawija lainnya. Terdapat kolam yang digunakan untuk budi daya ikan. Bahkan saat ini di lingkungan perkebunan pesantren telah dibangun tempat wisata dengan nama "Lintang Songo Green Garden", yang semua itu dikelola kiai Heri dan santri pada setiap harinya (Observasi, 12-14 Mei 2019).

Hal ini menjadi bukti bagaimana pondok pesantren Lintang Songo telah menggunakan lahan perkebunan dan persawahan sebagai jembatan interaksi kiai dengan santrinya. Yang menarik adalah ketika waktu-waktu tertentu, kiai Heri mengajak santrinya untuk mengurusi sawah dan kebun milik pesantren, ajakan untuk pergi ke sawah dilakukan oleh kiai dengan bahasa yang 'sangat egaliter', seperti kalimat, “Bagi (santri) yang selo (senggang) waktunya, jam 5 sampai jam 6 (pagi) bisa ke sawah bareng saya. Khusus bagi yang selo (senggang) saja, yang sibuk tidak perlu. Nuwun." Ajakan ini dilakukan melalui aplikasi WhatsApp ke pengurus pesantren untuk ditujukan ke semua santri (Fendi. 2019).

b. Lingkungan Sosial

Lingkungan sosial di sini merupakan organisasi sosial, stratifikasi, sosialisasi, gaya hidup dan seterusnya. Pondok pesantren Lintang Songo juga memiliki lingkungan sosial yang mengelilinginya. Lingkungan sosial pesantren tidak lepas dari pola hubungan sosial yang terjadi antara anggota-anggota masyarakat pesantren, mulai dari kiai, bu nyai, ustadz/ustadzah, santri putra/putri serta masyarakat sekitar lingkungan pesantren. Mungkin lingkungan sosial di pondok pesantren Lintang Songo sangat berbeda dengan pesantren pada umumnya. Di pesantren ini 
memiliki bentuk interaksi sosial yang sangat dinamis. Hubungan kiai dan bu nyai dan santri-santrinya memiliki hubungan yang intim. Saking intimnya, hubungan mereka sudah dianggap sebagai bagian keluarga sendiri. Seperti ketika ada santri yang kehabisan uang jajan (karena belum dikirim uang dari orang tua di rumah) dan kiai Heri mengetahuinya. Akhirnya, setiap hari santri tersebut diberi 'sangu' uang jajan ketika mau berangkat ke sekolah (Sugiman. 2019).

Terjadinya kontak sosial (baik kontak fisik maupun non fisik) satu sama lain inilah dengan sendirinya dapat memberikan makna relasi itu sendiri, seperti makna jabatan tangan santri ke kiai Heri yang memiliki tradisi yang berbeda. Senyuman kiai terhadap santri-santrinya yang khas, dan seterusnya. Semua menjadi simbol komunikasi lingkungan sosial yang menarik. Karena komunikasi merupakan bentuk penafsiran dan reaksi seseorang atas perilaku, sikap, pembicaraan, dan gerak tubuh untuk menyampaikan suatu maksud (Lukiati, 2019). Dengan komunikasi ini, lingkungan sosial menjadi dinamis dan praktis yang menyebabkan relasi kiai dan santri sangat mencair.

c. Lingkungan Simbolik

Gagasan mendasar yang menjadi sumber telaah adalah bahwa komunikasi terjadi melalui dunia simbol yang saling berkaitan. Kemudian konsep diri terbentuk melalui komunikasi, sehingga aktivitas sosial menjadi mungkin melalui proses pengambilan peran orang lain sebagaimana layaknya sandiwara dalam berkomunikasi (Syam, 2011:26). Dalam teori Kuntowijoyo, lingkungan simbolik meliputi makna dan komunikasi, seperti kata, mitos, seni, upacara, tingkah laku, benda-benda, dan seterusnya. Hal ini juga terlihat bagaimana lingkungan simbolik menjadi tampak nyata di pondok pesantren Lintang Songo ini.

Dalam perspektif santri, ada ruang makna simbol yang menjadi bagian lingkungan simbolik di pesantren yang ditujukan kepada sang kiai. Saking mengidolakan sosok kiai, bagi mereka kiai Heri adalah manusia 'sempurna' yang telah menjadi ayah sekaligus guru spiritual dan sosial. Tidak hanya itu, bagi santri, mungkin di seluruh pesantren lainnya, kiai 
juga disimbolkan sebagai agent of social and spiritual change dalam kehidupan mereka, seperti apa yang dikatakan oleh salah satu santri yang telah menjadi pengajar di pondok pesantren Lintang Songo di bawah ini:

"Bagiku, kiai Heri itu tidak hanya jadi orangtua, tetapi juga guru sekabehane (dalam segala hal), mas. Beliau itu kiai dan da'i, tentu beliau ahli agama. Beliau juga dosen sekaligus rektor di kampus. Beliau juga ahli bertani. Jaringan beliau sangat kuat, tidak hanya di berbagai daerah di Indonesia, tetapi juga antar negara. Pokok'e kita semua salut ke beliau. Rasanya sangat senang, beruntung hidup di pondok, bisa guyon bareng (bercanda tawa bersama) dan 'ngalap' (mencari) berkah di sini" (Rubiman. 2019).

Dalam konteks hasil percakapan santri senior di atas, terlihat bagaimana sosok kiai menjadi simbol idola bagi mereka. Kiai merupakan teladan bagi semua santri-santrinya. Oleh karenanya, sifat dan kepribadian serta tindakan kiai akan menjadi contoh nyata bagi santrinya bahkan menjadi tauladan bagi masyarakat di sekitarnya.

Bagi peneliti sendiri, sosok kiai Heri sendiri merupakan simbol yang unik. Ucapan dan sikapnya menyimbolkan seakan-akan, "saya tidak perlu dihormati seperti layaknya kiai lainnya." Ucapan yang humoris, sangat memahami dengan siapa ia berbicara, dan sikapnya yang cenderung mengayomi semua. Dengan bersikap 'kebapakan', kiai Heri selalu santai menanggapi apapun dinamika kehidupan. Ia seakan-akan menganggap semua hal pada dasarnya sudah biasa terjadi di dunia ini, maka harus dibuat biasa dan tidak perlu berlebihan dalam menanggapi. Maka dari itu, melalui ucapan dan sikapnya inilah lingkungan simbolik di pondok pesantren Lintang Songo terbentuk dengan baik. Sehingga dalam pendidikan, konstruksi relasi kiai dengan santrinya terlihat secara jelas bagaimana mereka satu sama lain memiliki simbol kebahagiaan, kekeluargaan, dan "keberkahan" dalam realitas kehidupan.

\section{F. Kesimpulan}

Pondok pesantren Lintang Songo memiliki sosok kiai yang sangat rasional dalam bertindak dan berkomunikasi dengan santrinya. Tidak hanya itu, sosok kiai ini memiliki 'aura' kharismatik tersendiri dibanding kiai-kiai di pesantren lainnya. 
Dialah KH. Heri Kiswanto atau sering disapa dengan kiai Heri. Ia bagi banyak kalangan merupakan sosok kiai yang unik. Keunikan beliau terletak cara relasinya. Yakni, pada cara bersikap dan berucap kepada santrinya dan masyarakat secara luas. Memahami hal tersebut, fenomena kepemimpinan kiai Heri ini bisa dikatakan sebagai "mix leadership". Dalam artian, kepemimpinannya memiliki sinergi satu sama lain, ia seorang yang kharismatik, juga rasional, dan partisipatif. Tentu pola kepemimpinan seperti ini tidak bisa disamaratakan dengan kepemimpinan-kepemimpinan pesantren di seluruh Indonesia. Karena pesantren satu dengan pesantren lainnya memiliki perbedaan yang (kadang) cukup signifikan.

Maka dari itu, analisa konstruksi pendidikan relasi kiai dan santri di pondok pesantren dengan menggunakan pendekatan Multidisipliner sangat tepat untuk diterapkan (yang dalam hal ini digunakan di pondok pesantren Lintang Songo). Karena dengan pendekatan Multidisipliner relasi keduanya mampu diuraikan secara komprehensif dan dapat diungkapkan melalui berbagai tinjauan dari sudut pandang ilmu yang berbeda.

\section{Daftar Pustaka}

Az Zanurji, Syaikh Burhanuddin. TT. Ta'limul Muta'allim. Terj. Kudus: Menara Kudus.

Hadari, Nawawi. 2003. Metode Penelitian Bidang Sosial. Yogyakarta: UGM Press.

Kuntowijoyo. 2006. Budaya dan Masyarakat. Yogyakarta: Tiara Wacara.

Lukiati, Komala. 2009. Ilmu Komunikasi: Perspektif, Proses, dan Konteks. Bandung: Widya Padjadjaran.

Mastuhu. 2004. Dinamika Pendidikan Pesantren. Jakarta: INIS.

Moleong, Lexy J. 2001. Metodologi Penelitian Kualitatif. Bandung: Rosdakarya.

Nata, Abuddin. 2016. Ilmu Pendidikan Islam. Jakarta: Kencana Prenada Media Group.

Nasution, Khoiruddin. 2016. Pengantar Studi Islam. Jakarta: PT RajaGrafindo Persada.

Masyhud, Sulthon. 2005. Manajemen Pondok Pesantren. Jakarta: Diva Pustaka.

Sudikan, Setya Yuwana Sudikan. TT. Pendekatan Interdisipliner, Multidisipliner dan Transdisipliner dalam Studi Sastra. Surabaya: UNS Press.

Sukmadinata, Nana Syaodih. 2008. Metode Penelitian Pendidikan. Bandung: Rosdakarya.

Sugiyono. 2015. Metode Penelitian Kualitatif. Cet. ke-22. Bandung: Alfabeta.

Syam, Nina W. 2011. Psikologi sebagai Akar Ilmu Komunikasi. Bandung: Simbiosa Rekatama. 
Jurnal dan Tesis:

Cenceng. 2015. Perilaku Kelekatan pada Anak Usia Dini (Perspektif John Bowlby). Jurnal Lentera. Vol IXX No 2.

Driyanti, Restituta. 2011. Makna Simbolik Tato bagi Manusia Dayak. Tesis. Jakarta: Universitas Indonesia.

Hidayah, Nurul. 2018. Kaderisasi Kepemimpinan Pesantren terhadap Putra Kiai, Studi Kasus di Pondok Pesantren Al-Iman Bulus Purworejo. Sangkep. Jurnal Studi Sosial Keagamaan. Vol. 1 Nomor 2.

Muzakki. 2013. Pengaruh Kepemimpinan Kiai terhadap Kecerdasan Emosi Santri di Pondok Pesantren Kebon Jambu Babakan Ciwangan Cirebon. Jurnal Holistik. Vol. 14 Number 01.

S, Hannah Fithrotien. 2015. Hubungan Antara Persepsi Santri Nahun Terhadap Figur Kiai. Tesis. Malang: UIN Malik Ibrahim.

Website:

Mahasin, Aswab. 2017. Dakwah Kultural Kiai Kampung. Diakses dari http://www.nu.or.id/post/read/80656/dakwah-kultural-kiai-kampung pada 14 Februari 2019 pukul 10.00 WIB.

NU Online. 2013. Pondok Pesantren Lintang Songo Bantul. Diakses dari http://www.nu.or.id/post/read/43550/pondok-aswaja-lintang-songo-bantul pada 24 Maret 2019 pukul 19.30 WIB.

\section{Observasi dan Wawancara:}

Hasil observasi di pondok pesantren Lintang Songo pada 12 Februari 2019 pukul 09.00 WIB.

Hasil observasi peneliti di Pondok Pesantren Lintang Songo pada 22-23 Januari 2019.

Hasil observasi peneliti di Pondok Pesantren Lintang Songo pada 12-14 Mei 2019.

Wawancara dengan kiai Heri (pengasuh Pondok Pesantren Lintang Songo) pada 12 Februari 2019 pukul 10.30 WIB.

Wawancara personal dengan ustaz Anwar (pengajar di Pondok Pesantren Lintang Songo) pada 24 Februari 2019 pukul 16.30 WIB.

Wawancara personal dengan Syifa (santri di Pondok Pesantren Lintang Songo) pada 25 Februari 2019 pukul 13.30 WIB.

Wawancara personal dengan Syifa (santri senior sekaligus ustadz di Pondok Pesantren Lintang Songo) pada 2 Maret 2019 pukul 15.00 WIB.

Wawancara personal dengan Sugiman, santri di Pondok Pesantren Lintang Songo pada 25 Februari 2019 pukul 08.30 WIB.

Wawancara personal dengan kiai Heri (Pengasuh Pondok Pesantren Lintang Songo) pada 24 Februari 2019 pukul 09.00 WIB.

Wawancara personal dengan Fendi, Sugiman, dan Heru (santri-santri senior di Pondok Pesantren Lintang Songo), pada 24 Februari 2019 pukul 11.30 WIB.

Wawancara personal dengan ustaz Rubiman (pengajar di Pondok Pesantren Lintang Songo) pada 2 Maret 2019 pukul 16.30 WIB. 